\title{
MANAJEMEN PUBLIKASI HASIL PENELITIAN PADA PUSAT STUDI UNIVERSITAS GADJAH MADA
}

\author{
Oleh :Sunarno
}

\begin{abstract}
Intisari
Manajemen publikasi hasil penelitian Pusat Studi di Universitas Gadjah Mada merupakan kegiatan dalam melaksankan fungsi-fungsi; perencanaan, pengorganisasian, pengkordinasian, pengelolaan personalia, dan pengawasan dalam kegiatan desiminasi publikasi terhadap hasil penelitian pusat studi. Kegiatan publikasi berfungsi sebagai sarana komunikasi antara para peneliti dengan masyarakat pengguna, civitas akademika maupun masyarakat umum. Secara fisik bentuk publikasi hasil penelitiin dapat berbentuk: Jurnal Ilmiah, Buku Monograf, Prosiding Seminar Hasil Penelitian, Buku Refensi, dan hasil penelitian yang didesirninasikan secara digital, diterbitkan dalam majalah ilmiah tingkat nasional dan tingkat internasional.

Indikator keberhasilan manajemen publikasi hasil penelitian pada pusat studi pada dasarnya ditunjukkan oleh besarnya kontribusi terhadap kemajuan ilmu pengetahuan, teknologi, dan seni. Indikator yang disebutkan ini sulit untuk mengukur keberhasilan, sehingga diperlukan indikator terukur yang rnudah, dievaluasi dan dikembangkan pada masa yang akan datang. Indikator-indikator keberhasilan publikasi hasil peneltian pada pusat studi dapat disebutkan: 1) jumlah publikasi dalam bentuk jurnal, prosiding seminar hasil penelitian, buku monograf, buku hasil penitian, hasil penelitian yang didesminasikan secara digital, diterbitkan dalam rnajalan ilmiah; 2) tingkat akreditasi jurnal yang dikelola pusat studi; 3) jumlah publikasi ilrniah pusat studi yang dimanfaatkan oleh masyarkat pengguna, dan 4) tingkat tanggapan atas pemanfaatan publikasi

Keberhasilan manajemen publikasi hasil penelitian pada pusat studi tidak hanya dimaknai sebagai penyokong terhadap kontribusinya bagi tercapainya misi universitas sebagai universitas riset, tetapi lebih dari itu dimaksudkan untuk pemanfaatan bagi masyarakat. Pemegang manajernen pada tingkat pusat studi ternyata mempunyai peranan yang sangat strategis dalam menentukan kebijakan dalam pencapaian kerberhasilan publikasi hasil penelitian. Setiap pusat studi mempunyai keberagaman dalam mengelola penyelenggaraan publikasi ilmiah, sehingga rnenghasilan kualitas publikasi ilmiah yang berbeda pula. Cara tepat untuk mengelola publikasi hasil penelitian adalah dengan cara-cara yang efektif dan efisien dalarn pelaksanaan fungsifungsi rnanajernen yang berlaku.

Hasil penelitian menunjukkan bahwa sebagian besar pusat studi telah melalukan publikasi hasil penelitian dengan standar sedang, hanya sebagian kecil pusat studi yang telah melakukan publikasi hasil penelitian dengan standar baik. Kondisi ini akan terus berubah seiring dengan perkembangan kebijakan IPTEKS dan didukung oleh kebijakan universitas.
\end{abstract}

Kata Kunci : Management, Research Publication

*) Pustakawan UGM

\subsection{Latár Belakang Masalah}

Salah satu misi Universitas Gadjah Mada dalam Rencana Strategis (Renstra) Universitas Gadjah Mada tahun 2008-2012 menyebutkan: "menjadi universitas riset dunia yang unggul, mandiri, bermartabat dan dijiwai Pancasila mengabdi kepada kepentingan dan kemakmuran bangsa". Misi universitas yang telah ditetapkan dan mempunyai makna yang tinggi ini dapat terealisasi apabila semua komponen universitas dapat mendukung dan melaksanakan tugas dan tanggungjawabnya sesuai dengan peran yang dimiliki dengan cara memanfaatkan berbagai sumberdaya yang dimiliki dengan manajemen yang efektif dan efisien.

Kedudukan Pusat Studi sangat penting dalam kontribusinya mewujudkan UGM sebagai universitas riset. Peraturan Rektor UGM nomor $246 / \mathrm{P} / \mathrm{SK} / \mathrm{HT} / 2007$ tentang penyelenggaraan pusat studi, pasal 3 menyebutkan bahwa pusat studi dibentuk dengan tujuan mengembangkan ilmu pengetahuan, teknologi, dan seni secara multi atau inter disiplin.' Kegiatan pusat studi meliputi penelitian, pelatihan dan pendidikan, pelayanan jasa ilrnu pengetahuan, teknologi, dan seni. Kegiatan utama penelitian dari pusat studi ini yang dijadikan alasan akan tuntutan terhadap layanan jasa ilmo pengetahuan dan teknologi melalui publikasi hasi] penelitian yang didiseminasikan kepada pengguna Selama satu tahun (2007) dari 27 pusat studi yan£ ada di UGM telah melakukan penelitian sebanyak 487 judul, pengabdian 203 judul, publikasi hasi penelitian 227 judul, penerbitan buku 108 judul, dar penerbitan jurnal ilmiah/buletin/prosiding berjumlah 20 kegiatan $^{2}$. Data ini menunjukkar

\footnotetext{
${ }^{1}$ Peraturan Rektor nomor 346/P/SK/HT/2008 Tentang Kinerja Riset UGM, 27 Juli 2008

${ }^{2}$ Laporan Rektor UGM tahun 2007 pada Peringatan Dies Natalis ke-5! tanggal 19 Desember 2007.
} 
bahwa keberadaan publikasi hasil penelitian di pusat studi cukup penting.

Para pemegang manajemen dan sumberdaya di pusat studi mempunyai peran yang sangat penting dalam mewujudkan pencapaian tujuan publikasi ilmiah. Tujuan publikasi ilmiah akan tercapai dengan baik apabila pemegang manajemen mampu mengelola publikasi hasil penelitian dengan caracara yang efektif dan efisien. Cara-cara efisien sebagai kemampuan untuk menyelesaikan suatu pekerjaan (kegiatan) dengan benar. Sedangkan efektivitas dimaksudkan merupakan kemampuan untuk memilih tujuan yang tepat atau peralatan yang tepat untuk pencapaian tujuan yang telah ditetapkan. Efisiensi dan efektifitas inilah yang biasa dianggap merupakan salah satu cara yang umum untuk mengukur suatu kerja (keberhasilan) organisasi.

\subsection{Perumusan Masalah}

Penelitian ini merumuskan pertanyaan pokok: "Bagaimana Pusat Studi di UGM mengelola manajemen publikasi hasil penelitiannya?" Pertanyaan pokok masalah ini memerlukan beberapa pertanyaan kunci yang meliputi: 1) pengelolaan manajemen hasil penelitian yang akan dipublikasikan; 2) pengelolaan manajemen pengolahan (proses) hasil-hasil penelitian menjadi bentuk-bentuk publikasi; 3) pengelolaan manajemen diseminasi hasil publikasi yang ditujukan ke pengguna; 4) pemanfaatan masukan (feedback) dari masyarakat pengguna untuk memperbaiki manajemen publikasi; 5) pemanfaatan peran unitunit universitas dalam mendukung terselenggaranya diseminasi publikasi; dan 6) pengembangan kerjasama dalam mendukung diseminasi publikasi ilmiah?

\subsection{Tujuan dan Manfaat Penelitian}

Penelitian manajemen publikasi ilmiah pada pusat studi di UGM ini bertujuan untuk mengetahui dan memahami manajemen publikasi ilmiah yang berlaku dengan cara mendiskripsikan keenam pokok permasalahan di atas. Manfaat akademis dari peneliian ini adalah dapat menambah pengetahuan secara substantif tentang manajemen publikasi ilmiah pada pusat studi di UGM. Sedangkan manfaat praktis dari hasil penelitian ini bagi pemegang manajemen pada tingkat universitas maupun pada tingkat pusat studi dapat menetapkan kebijakan yang tepat dalam manajemen publikasi ilmiahnya sehingga tujuan diseminasi dapat berjalan dengan baik dan pada akhirnya dapat mendukung pelaksanaan program-program pengabdian kepada masyarakat dengan cara pemberian layanan berupa hasil (bentuk) publikasi hasil penelitian.

\subsection{Kerangka Pemikiran}

Kebutuhan akan manajemen dalam semua kegiatan publikasi hasil penelitian pada pusat studi adalah pertama untuk mencapai tujuan publikasi hasil penelitian; kedua untuk menjaga keseimbangan di antara tujuan-tujuan yang saling bertentangan, dan ketiga untuk mencapai efisiensi dan efektifitas. Efisiensi dimaksudkan sebagai kemampuan untuk menyelesaikan suatu pekerjaan dengan benar, sedangkan efektivitas merupakan kemampuan untuk memilih tujuan yang tepat atau peralatan tepat untuk pencapaian tujuan yang telah ditetapkan

Dalam penyelenggaraan manajemen publikasi hasil penelitian pusat studi-pusat studi di UGM mempunyai keberagaman dan keunikan masingmasing. Keberagaman ini mencakup: pertama, aspek berlakunya fungsi-fungsi manajemen (perencanaan, pengorganisaian, pengkoordinasian, pengawasan dalam semua tahapan proses publikasi (pengelolaan hasil, proses pengolahan bentuk publikasi, diseminasi, dan umpan balik), kedua aspek pengembangan kerjasama publikasi hasil penelitian antar unit di UGM dan kerjasama dengan instansi lain. Kedua aspek keberagaman berlakunya penyelenggaraan manajemen publikasi hasil penelitian ini akan menjadi dasar untuk memberikan penilaian ke dalam beberapa kategori tingkatan standar tertentu. Peneliti akan membagi ke dalam tiga tingkatan penyelenggaraan manajemen publikasi hasil penelitian yaitu: tingkat pertama sebagai berstandar baik, tingkat kedua berstandar sedang, dan tingkat ketiga berstandar rendah. Ketiga kategori penilaian dianggap memenuhi syarat mengingat semua pusat studi yang dijadikan obyek (sampel) penelitan adalah pusat studi yang telah melaksanakan publikasi hasil penelitian dalam bentuk dan periode tertentu.

Fungsi-fungsi manajemen yang bersifat universal berlaku juga pada pengelolaan manajemen publikasi hasil penelitian di pusat studi. Fungsifungsi tersebut adalah perencanaan, pengorganisasian, pengkoordinasian/ pengarahan, pengawasan/ pengendalian dan fungsi lainnya. Fungsi-fungsi manajemen akan berlaku dalam semua tahapan proses publikasi hasil penelitian yang merupakan alur yang terus menerus yang dapat berfungsi sebagai sistem informasi seperti yang terlihat dalam bagan berikut: 
Bagan Nomor : 1

Fungsi-fungsi Manajemen dalam Proses Publikasi Ilmiah

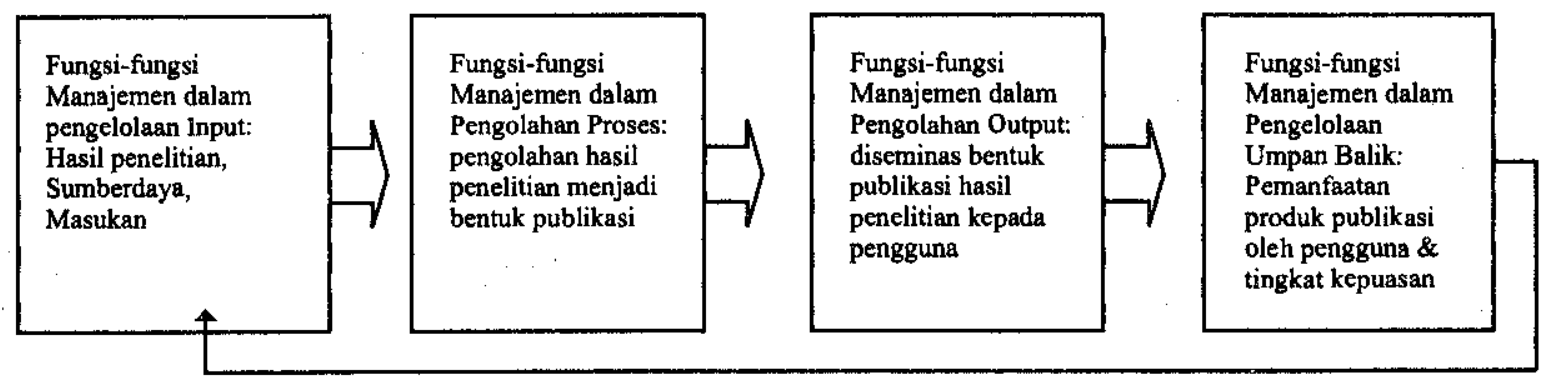

Dari bagan di atas terlihat bahwa proses manajemen publikasi ilmiah berjalan secara terus menerus. Sebuah hasil penelitian yang diserahkan oleh seorang peneliti (biasanya buku laporan penelitian) oleh peneliti ini perlu penanganan sebelum dibawa ke proses pengolahan menjadi bentuk publikasi hasil penelitian. Hasil penelitian yang telah dikelola ini akan berfungsi sebagai input utama dalam manajemen publikasi hasil penelitian.

\subsection{Metode Penelitian}

\subsubsection{Jenis Penelitian}

Penelitian ini menggunakan pendekatan atau metode kualitatif. Peneliti bertujuan untuk menjelaskan fenomena dengan sedalam-dalamnya melalui pengumpulan data sedalam-dalamnya pada berbagai aspek yang berhubungan dengan manajemen publikasi ilmiah pada pusat studi di UGM. Penelitian ini tidak akan mengutamakan besarnya populasi atau sampling. Populasi atau sampling dalam penelitian adalah sangat terbatas. Peneliti memilih 10 pusat studi yang telah menyelenggarakan publikasi terhadap hasil penelitiannya.

\subsubsection{Lokasi Penelitian}

Penelitian ini dilakukan pada 10 (sepuluh) pusat studi di lingkungan UGM Yogyakarta. Pemilihan lokasi ditentukan secara sengaja (purposive). Pertimbangan ini didasarkan pada besarnya jumlah publikasi yang dihasilkan selama tahun 2007. Dari sepuluh pusat pusat studi yang dijadikan lokasi penelitian menunjukkan bahwa selama tahun 2007,8 pusat studi telah menghasilkan publikasi hasil penelitian di atas 20 judul yaitu Pusat Studi Bioteknologi, Pusat Studi llmu Teknik, Pusat Studi Kependudukan dan Kebijakan, Pusat Studi Transportasi dan Logistik, Pusat Studi Ekonomi Kerakyatan, Pusat Studi Lingkungan Hidup, Pusat Studi Pancasila, dan Pusat Studi Sosial Asia Tenggara, dan Pusat Studi Ekonomi dan Kebijakan
Publik. Dua pusat studi yang telah menghasilkan publikasi hasil penelitian terhadap penelitiannya di bawah 20 judul adalah Pusat Studi Pangan dan Gizi, dan Pusat Studi Korea.

\subsubsection{Teknik Pengumpulan Data}

Penelitian ini akan menggunakan metode wawancara mendalam (depth interviews) dan metode observasi dalam pengumpulan data. Peneliti akan menggunakan metode wawancara mendalam dengan melakukan kegiatan wawancara tatap muka secara mendalam dan terus menerus (lebih dari satu kali) untuk menggali informasi dari informan sebagai sumber informasi atau data (intensiveinterviews).

Penggunaan gabungan metode wawancara mendalam dan metode observasi nonpartisipan ini merupakan pendekatan konstruktivis, yaitu menganggap bahwa realitas ada dalam pikiran subyek yang diteliti, yaitu para pimpinan pusat studi, pengelola publikasi, petugas dan atau karyawan yang terlibat dalam aktivitas penyelenggaraan publikasi hasil penelitian pusat studi. Penelitian ini akan menggunakan instrumen penelitian sebagai alat bantu untuk mengumpulkan data agar kegiatan itu menjadi sistematis dan dipermudah olehnya. Instrumen ini berbeda dengan metode pengumpulan data yang masih bersifat abstrak, maka instrumen penelitian merupakan sarana yang bisa diwujudkan dalam bentuk benda . Dalam penelitian ini metode pengumpulan data dengan wawancara menggunakan instrumen: 1) pedoman wawancara (interview guide); 2) daftar cocok (checklist). Sedangkan dalam metode oberservasi nonpartisipan peneliti akan menggunakan instrumen: 1) lembar pengamatan; 2) daftar cocok.

\subsubsection{Analisis Data}

Data-data yang terkumpul dalam penelitian ini adalah data kualitatif yang berupa: kata-kata, kalimat-kalimat atau narasi-narasi, baik yang 
diperoleh dari wawancara mendalam maupun observasi. Peneliti akan memberi makna atas data yang merupakan kunci untuk menuju data reliabilitas dan validitas, dan ini terletak pada peneliti sebagai instrumen penelitian. Penelitian ini akan menggunakan cara berpikir induktif, yaitu cara berpikir yang berangkat dari hal-hal yang khusus (fakta empiris) menuju hal-hal yang umum (tataran konsep). Analisis data dimulai dari berbagai data yang berhasil dikumpulkan peneliti di lapangan. Data yang terkumpul baik melalui wawancara maupun observasi mendalam kemudian diklasifikasikan ke dalam kategori-kategori tertentu. Pengklasifikasian atau pengkategorian dengan mempertimbangkan kesahihan (kevalidan), dengan memperhatikan kompetensi obyek penelitian, tingkat keaslian dan kebenaran terhadap berbagasi sumber.

Setelah data diklasifikasikan, peneliti akan melakukan pemaknaan terhadap data, yang merupakan prinsip dasar dalam penelitian kualitatif, yaitu bahwa realitas ada pada pikiran manusia, realitas adalah hasil konstruksi sosial manusia. Dalam melakukan pemaknaan atau interpretasi, peneliti akan berpikir (berteori) untuk menjelaskan dan berargumen. Setelah intepretasi peneliti lakukan, temuan-temuan akan dianalisa dengan berbagai konteks berjalannya manajemen publikasi hasil penelitian pada pusat studi di UGM yang melatarbelakangi fenomena yang diteliti.

\section{Temuan dan Analisis Manajemen Publikasi Hasil Penelitian \\ 2.1. Temuan Penelitian \\ 2.1.1. Berjalannya Fungsi-Fungsi Manajemen Publikasi Hasil Penelitian}

Pertanggungjawaban perencanaan publikasi tergantung pada besar dan tujuan publikasi di pusat studi. Perencanaan publikasi di pusat studi lebih cenderung hanya membuat rencana-rencana jangka pendek, khususnya publikasi dalam bentuk temu ilmiah sangat dipengaruhi oleh kegiatan penelitian yang dilaksanakan. Sementara perencanaan kegiatan publikasi jurnal lebih pasti, karena kegiatan ini merupakan kegiatan rutin atau periodik, sehingga perencanaan tenaga, pengolahan, diseminasi, dan penganggaran lebih mapan keberadaannya.

Sebagian besar pusat studi yang menyelenggarakan publikasi tidak membentuk unit publikasi secara formal. Walaupun secara formal tidak terbentuk unit publikasi tetapi fungsi manajemen publikasi tetap berjalan dan berlaku. Kebanyakan pusat studi mempunyai struktur yang ringkas dan ramping kondisi berdasar pada kenyataan bahwa kegiatan publikasi di pusat studi belum membutuhkan struktur yang luas, mengingat volume kegiatan khususnya penelitian sangat tidak menentu. Karena unit atau urusan publikasi tidak mempunyai unit tersendiri maka penanggungjawab pun juga dirangkap oleh pejabat tertentu.

Hal-hal yang sering menjadi kendala dalam koordinasi dalam pelaksanaan pengelolaan manajemen publikasi hasil penelitian terhadap hasil penelitian antara lain berkaitan dengan orientasi para pelaksana, waktu pelakanaan, hubungan personal para petugas, dan perbedaan kepentingan antar unit yang ada di pusat studi. Melihat rentang manajemen yaitu jumlah bawahan (karyawan) yang dapat dikendalikan secara efektif oleh pengelola atau pengelola publikasi adalah cukup pendek. Kondisi ini dapat dimengerti karena pada unit publikasi untuk saat ini belum memerlukan tenaga atau karyawan cukup banyak, cukup memanfaatkan pegawai yang sudah ada. Oleh karenanya koordinasi terhadap mereka sebenarnya tidak begitu sulit.

Hal-hal yang menjadi tugas pengelola publikasi terhadap bawahan atau karyawan berhuhungan dengan situasi yang rutinitas, pengolahan, rincian tugas, prosedur kerja. Sementara hubungan yang lain adalah seperti hubungan atasan dan bawahan. Hubungan-hubungan ini bisa dipengaruhi oleh kemampuan (keterlatihan) bawahan, kesenangnan terhadap pekerjaan, kemampuan atasan, gaya kepempimpinan.

Fungsi-fungsi pokok dalam kegiatan publikasi hasil penelitian dapat disebutkan; 1) fungsi pengolahan, yaitu semua aktivitas untuk mengolah input atau hasil penelitian menjadi bentuk-bentuk publikasi; 2 fungsi pemasaran dan atau layanan, fungsi ini meliputi kegiatan penyaluran output (hasil dalam bentuk-bentuk publikasi hasil penelitian) yang ditujukan kepada pengguna; 3) fungsi pembiayaan, fungsi ini dampak dari semua kegiatan yang dilakukan, mulai dari pengolahan input sampai pada layanan publikasi.

Sumberdaya terpenting dalam suatu pusat studi adalah sumberdaya manusia, yaitu orang-orang yang memberikan tenaga, bakat, kreativitas, dan usaha mereka kepada pusat studi. Beberapa tugas kepemimpinan oleh kepala pusat studi dalam aktivitas publikasi mencakup penarikan, penyeleksian, pengembangan dan penggunaan sumberdaya dalam mencapai tujuan publikasi hasil penelitian. Tanpa orang-orang yang cakap, aktivitas publikasi dan manajemennya akan bisa gagal mencapai tujuan.

Pada umumnya pusat studi, semakin besar 
lingkup kegiatan publikasi mempengaruhi jumlah karyawan yang dibutuhkan. Sementara sumber daya personalia yang dibutuhkan dipenuhi berasal dari dua sumber, yaitu dari dalam pusat studi yaitu mengadakan karyawan tetap, dan kedua mengambil dari luar pusat studi sebagai tenaga by project.

Kompensasi adalah sangat penting bagi karyawan sebagai individu karena upah merupakan satu ukuran nilai atau karya mereka diantara para karyawan itu sendiri, keluarga, dan masyarakat. Tingkatan pendapatan absolut karyawan akan menentukan skala kehidupannya, dan pendapatan relatif mereka menunjukkan status, martabat, dan harganya. Kompensasi juga penting bagi pusat studi, karena jumlah pembayaran kepada karyawan dalam bentuk pengupahan dan balas jasa lainnya sering merupakan komponen biaya yang paling besar dan penting. Kompensasi mempunyai dampak penting terhadap tingkat ekonomi karyawan.

Pada umumnya karyawan akan menerima perbedaan pengupahan yang berdasarkan perbedaan tanggungjawab, kemampuan, pengetahuan, dan produktivitas. Beberapa pusat studi dalam menentukan besaran kompensasi dengan beberapa pertimbangan antara lain: 1) kesediaan membayar oleh penentu kebijakan, 2) kemampuan membayar oleh pusat studi, 3) persyaratan pembayaran yang harus dipenuhi.

Kendala utama dalam pengembangan dan pengelolaan kebutuhan personalia di pusat studi dalam penanganan publikasi hasil penelitian adalah masalah pendanaan. Semua pendanaan pusat studi termasuk penggajian petugas non PNS adalah menjadi tanggungan pusat studi, sementara permintaan akan alokasi pegawai PNS dari UGM cukup sulit, kecuali mereka yang diangkat sebagai PNS dengan menjadi tenaga honorarium di pusat studi.

Pengawasan publikasi dimaksudkan sebagai proses untuk "menjamin" bahwa tujuan-tujuan yang ditentukan dapat terlaksana. Tidak dijumpai prosedur pengawasan menggunakan cara-cara tertentu yang tersurat secara pasti, tetapi pengawasan dilakukan lebih fleksibel mengingat kegiatan publikasi belum menjadi skala prioritas program. Kini belum adanya aturan yang ketat dari universitas tentang penyelenggaraan publikasi hasil penelitian di pusat studi.

\subsubsection{Tahapan Proses Manajemen Publikasi Hasil Penelitian}

Tindak lanjut terhadap pengelolaan hasil penelitian adalah pengelolaan proses pengolahan (produksi) hasil penelitian menjadi bentuk-bentuk publikasi hasil penelitian. Manajemen pengolahan ini bertujuan untuk mengatur penggunaan resources (faktor-faktor produksi) yang ada baik yang berupa bahan (hasil penelitian), tenaga kerja, mesin dan peralatan, perlengkapan, sedemikian rupa sehingga proses produksi publikasi dapat berjalan dengan efektif dan efisien. merupakan bagian yang akan melaksanakan kegiatan untuk menciptakan kegunaan atau utitility. Kegiatan pelaksanaan publikasi terutama adalah dalam menciptakan bentuk atau form utility, disamping itu juga menciptakan kegunaan tempat (place utility), kegunaan waktu (time unitility).

Secara fisik, publikasi dapat berbentuk antara lain berupa buku monograf, buku referensi, hasil penelitian dan pemikiran yang didiseminasikan secara digital, diterbitkan dalam majalah ilmiah nasional atau internasional, atau dipublikasikan melalui seminar. Hampir semua pusat studi mempunyai produk atau bentuk publikasi hasil penelitian dari hasil proses pengolahannya. Relatif sangat sedikit pusat studi yang memiliki bentukbentuk publikasi hasil penelitian untuk semua yang disebutkan. Sebagian besar bentuk publikasi hasil penelitian yang dihasilkan oleh pusat studi adalah buku laporan penelitian. Sedangkan bentuk publikasi yang menduduki dibawahnya adalah buku atau kumpulan makalah, dan prosiding seminar hasil penelitian, hampir semua pusat studi memiliki. Khusus bentuk publikasi hasil penelitian yang berwujud jurnal ilmiah sangat sedikit, dari jurnal ilmiah yang ada jurnal ilmiah dengan standar internasional paling sedikit, sebagian besar jurnal yang ada di pusat studi adalah jurnal ilmiah akreditasi nasional, dan jurnal ilmiah tingkat lokal atau majalah ilmiah relatif sedikit. Bentuk-bentuk publikasi yang didokumentasikan dengan media lain (digital) pada pusat studi masih jarang dilakukan (diproduksi).

Sebagian besar pusat studi dalam pemenuhan standar publikasi ilmiah dari hasil penelitian belum melakuan mekanisme berikut: 1) belum dibuat aturan yang mewajibkan peneliti mempresentasikan hasil penelitiannya dalam pertemuan ilmiah, atau mempublikasikannya dalam jurnal ilmiah nasional atau internasional; 2) belum mewajibkan peneliti untuk menyisihkan dana penelitian untuk publikasi; 3) belum perlu mengalokasikan dana insentif untuk naskah yang berhasil dimuat dalam jurnal internasional. Pengendalian mutu publikasi di pusat studi dilakukan adalah dengan cara, pengendalian melalui penilai dan tim penilai kelayakan jumal, adalah dengan cara: 1) menerapkan kaidah 
penggunaan ejaan bahasa Indonesia dan Inggris dalam publikasi hasil penelitian; 2) menginformasikan kepada penulis tentang syaratsyarat kalimat efektif dan komposisi paragraf; 3) penyusunan. wacana menulis ilmiah; 4) menginformasikan kepada penulis tentang contohcontoh publikasi hasil penelitian. Penerapan cara yang berbeda dalam pemenuhan standar (mutu) publikasi hasil penelitian pada pusat studi, sampai kini belum dapat disimpulkan hasil dari cara yang ditempuh untuk pemenuhan standar publikasi hasil penelitian.

Diseminasi berarti kegiatan menyebarluaskan suatu doktrin atau pemikiran. Diseminasi juga berarti suatu proses penyerbaluasan hasil penelitian dan pengkajian kepada pengguna, yang merupakan bagian integral dari kegiatan penelitian yang dilakukan. Hasil penelitian dapat disebarluaskan melalui berbagai media komunikasi, dan ini dimaksudkan untuk menjangkau sasaran pengguna yang lebih luas. Diseminasi publikasi hasil penelitian kedudukannya sangat penting, karena dapat digunakan sebagai indikator untuk mengetahui dan mengukur kualitas penelitian melalui publikasi pada jurnal ilmiah yang bermutu dan atau publikasi melalui pertemuan ilmiah baik skala nasional maupun internasional.

Hampir semua pusat studi telah menyelenggarakan diseminasi terhadap hasil penelitiannya. Ada sebagian pusat studi dalam penyelenggaraan diseminasasi dipadukan dengan kegiatan penelitian secara keseluruhan, namun ada juga pusat studi yang memisahkannya. Kegiatan diseminasi hasil penelitian yang dipisahkan dari kegiatan penelitian biasanya dilakukan oleh pusat studi yang menyelenggarakan kegiatan penelitian dengan dana yang terbatas atau anggaran kegiatan publikasi tidak dimasukkan ke dalam anggaran penelitian yang bersangkutan. Pusat studi dalam kasus ini adalah dengan mencari atau mengadakan kerjasama dengan pihak lain seperti dengan penerbit, atau mengadakan seminar hasil penelitian dengan mencari sponsor atau penyandang dana baik kalangan usaha maupun kerjasama dengan instansi tertentu. Oleh karenanya idealisme diseminasi hasil penelitian adalah tergantung dari dana penyelenggaraan sebagai tulangpunggungnya.

Dengan kondisi yang demikian maka pusat studi dalam penentuan dalam perbaikan dan pengembangan penjaminan kualitas layanan publikasi hasil penelitian dalam diseminasinya dilakukan secara sepihak atau dilakukan oleh pusat studi sendiri sebagai penyedia layanan. Kondisi ini menjadikan pusat studi tidak pernah tahu secara lebih banyak yang diharapkan oleh para pengguna publikasi ilmiah dari hasil penelitiannya, sehingga pusat studi sebenarnya tidak bisa melakukan perubahan dalam pengembangan untuk menuju layanan kepada yang terpuaskan karena tercukupi kebutuhan ilmiahnya. Kondisi ini sangat disayangkan, mengingat perlakuan umpan balik sangat diperlukan dalam perbaikan menuntut layanan yang optimal kepada publik, apalagi kebaradaan pusat studi adalah semua dibawah naungan nama besar UGM.

\subsubsection{Pengembangan dan Kerjasama Publikasi Hasil Penelitian}

Pusat studi dalam mengembangkan publikasi hasil penelitian dari berbagai hasil penelitiannya dirasa belum optimal dalam memanfaatkan berbagai peluang kerjasama dengan berbagai unit di UGM maupun antar instansi baik dalam maupun luar negeri.

Pusat studi belum memanfaatkan keberadaan dan peran LPPM UGM dalam hal pengembangan publikasi hasil penelitian terhadap hasil penelitiannya. Padahal LPPM UGM memiliki rincian tugas antara lain; 1) memfasilitasi sarana dan prasarana penelitian yang diakses dan dimanfaatkan sivitas akademika; dan 2) menyusun basis data hasil penelitian serta pemanfaatannya, serta mengembangkan publikasinya. Khusus untuk poin kedua pusat studi kini masih enggan memasukkan data penelitiannya dalam database yang dikembangkan LPPM, padahal ini merupakan saranayang tepat sebagai saranan publiksai ilmiah.

Sekolah pascasarjana yang kini mengelola program multi, lintas, interdisipliner ilmu baik untuk program S2 maupun S3. Beberapa program studi tertentu dilahirkan dari inisiatif para ahli dan pengelola pusat studi misalnya program studi bioteknologi sangat erat hubungan ilmu dan proses lahirnya program studi tersebut. Program Studi Kependudukan dan Kebijakan juga sangat erat hubungannya dengan Pusat Studi Kependudukan dan Kebijakan, Program Studi Resulusi Konflik sangat dekat hubungannya dengan Pusat Studi Keamanan dan Perdamaian. Hubungan erat antara sekolah pascasarjana dengan pusat studi tidak sebatas yang disebutkan, tetapi lebih dari itu. Beberapa program studi S2 telah menjalin kerjasama dengan pusat studi dalam hal pelaksanaan penelitian tesisnya. Contoh dari kasus ini dapat disebutkan; mahasiswa S3 atau S2 bidang ilmu teknik kini dalam penelitian tesis ataupun disertasinya menggunakan fasilitas pada Laboratorium di Pusat Studi Ilmu 
Teknik. Hubungan yang lebih menarik adalah bahwa mahasiwa yang telah selesai melakukan penelitian dengan menggunakan fasilitas pusat studi diwajibkan untuk mempublikasikan karya ilmiahnya di pusat studi, baik dalam bentuk publikasi dengan presentasi (oral presentation) yaitu dalam forum seminar, diskusi ilmiah, dan pertemuan ilmiah lainnya, maupun juga dengan melalukan publikasi cetak seperti pada prosiding seminar, buku laporan ilmiah dan publikasi lewat media massa.

Pusat studi dalam menyelenggarakan kegiatan publikasi hasil penelitian terhadap hasil penelitiannya tidak terlepas dari ikatan kerjasama dengan institusi lain. Bentuk-bentuk kerjasama bidang penelitian dengan institusi lain bisa dalam rangka kegiatan yang saïing menguntungkan. Pengembangan kerjasama dengan intitusi dengan pihak-pihak yang terakait dengan bidang disiplin ilmu yang dikembangkan adalah merupakan tulang punggung bagi keberlangsungan kehidupan pusat studi. Institutusi atau lembaga yang selama ini telah dibangun untuk mengadakan kerjasama penelitian berasal dari instansi pemerintah baik instansi pusat maupun pemerintah daerah. Kerjasama sama dengan non pemerintah berasal dari kalangan dunia usaha, lembaga swadaya masyarakat, dan juga lembaga pendidikan lainnya. Pengembangan kerjasama kegiatan publikasi hasil penelitian dengan instansiinnstansi pemerintah pusat meliputi departemendepartemen terkait dan mempunyai kajian pengembangan multidisplin ilmu yang relevan.

\subsubsection{Tingkat Keberhasilan Manajemen Publikasi Hasil Penelitian}

Hasil penelitian yang dilakukan oleh para peneliti pusat studi, setelah selesai melakukan kegiatan penelitian maka hasil penelitian juga diseminarkan. Proses pembuatan artikel atau makalah seminar dari hasil penelitian yang telah dilaporkan merupakan tugas para peneliti. Namun demikian jika ternyata kegiatan seminar untuk pembahasan hasil penelitian tidak bisa diselenggarakan, maka makalah atau artikel-artikel tersebut akan dipublikasi melalui layanan perpustakaan pusat studi.

Ada sebagian kecil pusat studi yang sebenarnya mempunyai banyak sumberdaya manusia terdiri dari pimpinan, staf ahli, staf peneliti, didukung oleh banyaknya tenaga laboran dan tenaga administratif. Disamping itu juga memiliki fasilitas laboratorium yang memadai yang selalu dimanfaatkan oleh mahasiswa S1, S2 untuk melakukan penelitian skripsi atau tesisnya, juga mempunyai sebuah perpustakaan dengan ruangan yang luas dan dikelola oleh pustakawan yang berstatus PNS. Tetapi publikasi dengan penerbitan jurnal ilmiah banyak menemui kendala. Alasan yang muncul sebagai kendala adalah 1) adanya kendala dana pembiayaan penerbitan dan diseminisasinya; 2) adanya pergantian pimpinan pusat studi yang tidak mempunyai komitmen yang kuat untuk penyelenggaraan publikasi penerbitan jurnal; 3) kesulitan mencari penyandang dana dalam proses penerbitan dan proses produksi maupun penyebarluasannya; 4) tenaga-tenaga yang profesional, dan tenaga ahli banyak meninggalkan pusat studi karena berbagai alasan; dan 5) kendala lain yang bersifat teknis.

\subsection{Analisis Manajemen Publikasi Hasil Penelitian}

- Pengelola publikasi hasil penelitian pusat studi di UGM tidak mempunyai jabatan struktural formal, sehingga tidak ada standarisasi tugas dan tanggung-jawab dalam menjalankan fungsi administratif maupun fungsi operatif. Setiap pusat studi memiliki kebijakan yang berbeda atas penyelenggaraan publikasi hasil penelitiannya, sehingga kondisi ini mempengaruhi kinerja para pengelola publikasi.

- Sebagian besar pusat studi dalam menjalankan fungsi-fungsi manajemen publikasi hasil penelitiannya dihadapkan pada berbagai kendala yang merupakan hambatan dalam mencapai tujuan publikasi. Pusat studi dalam perencanaan publikasi hasil penelitian belum ditempatkan sebagai program kegiatan yang utama, tetapi masih ditempatkan sebagai bagian dari perencanaan kegiatan penelitian secara keseluruhan. Perencanaan publikasi lebih ditekankan pada perencanaan jangka pendek menyesuaian kegiatan penelitian yang ada. Keterbatasan pendanaan merupakan kendala utama dalam merencanaan program kegiatan publikasi. Para petugas atau karyawan banyak yang tidak memahami terhadap perencanaan publikasi karena mereka tidak dilibatkan dalam proses perencanaan, sehingga mereka hanya menerima tugas rutin atau menunggu perintah. Sebagian besar perencanaan publikasi tidak dimasukkan ke dalam Rencana Kegiatan dan Anggaran Tahunan.

- Pusat studi dalam penyusunan strukur organisasi sebagian besar tidak menempatkan bidang (urusan) publikasi hasil penelitian ke dalam struktur formal, tetapi kegiatan publikasi merupakan bagian dari divisi penelitian. 
Rampingnya struktur organisasi pusat studi menyebabkan tanggungjawab kegiatan publikasi dirangkap oleh penanggungjawab pada unit yang lain. Hanya pusat studi yang memiliki kegiatan penelitian yang berjumlah banyak dan dengan dana besar saja yang memiliki unit publikasi tersendiri. Beberapa kelemahan pusat studi dengan tidak membentuk unit atau divisi publikasi antara lain: 1) tidak terintegrasi dalam pengaturan kegiatan, keterampilan, keahlian dalam memproduksi dan memasarkan jasa publikasi; 2) prestasi kerja yang tinggi sulit dicapai karena keseluruhan pekerjaan yang berhubungan dengan publikasi sulit dikoordinasi; 3) tidak adanya kecepatan dalam pembuatan keputusan yang tepat dan sangat diperlukan karena tidak ditangani oleh unit tersendiri. Sebagian kecil pusat studi membentuk kelompok kerja formal, baik panitia tetap maupun panitia khusus, keduanya berfungsi menangani tugas khusus publikasi karena tuntutan akhir dari kegiatan penelitian.

- Pengkoordinasian kegiatan manajemen publikasi hasil penelitian di pusat studi kebanyakan tidak mempertimbangkan aspekaspek yang esensial, antara lain: aspek internal meliputi jumlah dan beban tugas karyawan, pengelola unit, sarana pendukung, prosedur kerja. Dari aspek eksternal meliputi: perkembangan IPTEKS, peluang kerjasama, tuntutan pihak luar, dan lingkungan sekitar. Kendala-kendala yang dihadapi dalam koordinasi kegiatan publikasi antara lain; orientasi para petugas, waktu pelaksanaan, hubungan personal para petugas, perbedaan kepentingan antar unit. Dalam rentang koordinasi dalam kegiatan publikasi di pusat studi cukup pendek, sehingga tidak memerlukan tenaga yang cukup banyak. Fungsi-fungsi pokok dalam koordinasi kegiatan publikasi adalah fungsi pengolahan, fungsi pemasaran dan layanan, dan fungsi pembiayaan. Pengkoordinasian pada pusat studi dilengkapi dengan menunjukkan staf yang berfungsi sebagai pemberi saran dan pelayanan kepada fungsi ini.

- Pengelolaan personalia dalam kegiatan publikasi hasil penelitian pusat studi meliputi; kebutuhan sumberdaya manusia, cara menarik dan menyeleksi orang ke posisi potensial, pemberian latihan kepada petugas, dan penyusunan program pengembangan personalia. Pengelolaan personalia yang menyangkut spesifiksi dan jenis jabatan, ketrampilan yang dimiliki, estimasi jumlah personal, sebagian besar pusat studi mensinkronkan dengan volume kegiatan, khususnya kegiatan penelitian. Tidak ditemukan kendala dalam pengelolaan personalia, kondisi terjadi mengingat penyelenggaraan publikasi belum memerlukan tenaga dengan jumlah yang besar.

- Sebagian besar pusat studi tidak dijumpai prosedur pengawasan dengan menggunakan cara-cara tertentu yang tersurat secara pasti, tetapi pengawasan dilakukan dengan cara yang sangat fleksibel. Kondisi ini didukung oleh kenyataan bahwa universitas belum mengeluarkan kebijakan tertentu dalam publikasi hasil penelitian di pusat studi sebagai acuannya. Pengawasan yang berlaku kini belum menunjukkan adanya hubungan yang erat antara perencanaan dengan pengawasan. Kondisi ini disebabkan oleh belum adanya penetapan standar dalam pelaksanaan pengawasan. Perencanaan publikasi yang tidak sistematik terjadi dalam hal; tujuan perencanaan, perancangan sistem informasi umpan balik, pembandingan kegiatan nyata dengan standaryang ditetapkan.

- Hasil penelitian yang dilaksanakan oleh pusat studi merupakan hasil intelektual yang diyakini dapat memecahkan suatu masalah di bidang IPTEKS yang bermanfaat bagi manusia. Agar mudah diterima dan dimanfaatkan oleh masyarakat, hasil penelitian perlu diolah untuk diwujudkan dalam bentuk-bentuk publikasi seperti jurnal, makalah, maupun bentuk lainnya. Sebagian besar pusat studi belum melakukan pengolahan hasil penelitian ke dalam bentuk yang ideal, tetapi fungsi publikasi dan diseminasi tetap berjalan dengan cara melayankan bentuk-bentuk asli dari laporan penelitian kepada masyarakat.

- Pengolahan hasil penelitian menjadi bentukbentuk publikasi memerlukan manajemen pengolahan. Pusat studi dalam menggunakan faktor-faktor produksi (resources) berupa bahan, tenaga kerja, mesin, peralatan, perlengkapan dalam proses produksi bentuk publikasi belum berjalan efektif dan efisien. Kondisi ini ditandai oleh penggunaan resources yang begitu besar belum dicapai mutu yang baik, dan proses produksi dengan biaya yang besar pun tidak terjadi ketepatan waktu penyelesaian. Kegiatan ini sebenarnya untuk 
keperluan menciptakan kegunaan dengan menginterasikan antara bahan, tenaga kerja, mesin/peralatan, maupun perlengkapan. Pusat studi dalam menghasilkan bentuk-bentuk publikasi ilmiah seperti buku monograf, buku referensi, hasil penelitian yang didiseminasikan secara digital, diterbitkan dalam majalah ilmiah nasional dan internasional, atau dipublikasi melalui seminar masih sangat minim. Jumlah yang relatif banyak dalam bentuk publikasi hasil penelitian adalah diseminasi oral presentation atau temu ilmiah mengingat kegiatan publikasi ini berhubungan langsung dengan kegiatan penelitian secara keseluruhan.

- Bentuk-bentuk publikasi hasil penelitian pada pusat studi sebagian besar kurang berkualitas, kondisi ini dipengaruhi oleh 1) kebanyakan pusat studi tidak mewajibkan para peneliti mempublikasikan; 2) tidak adanya aturan standarisasi bentuk-bentuk publikasi hasil penelitian pada pusat studi; 3) sedikitnya pusat studi yang mengalokasikan dana untuk kegiatan publikasi hasil penelitian; 4) kurangnya program pelatihan bagi para peneliti dalam kegiatan publikasi ilmiah.

- Publikasi ilmiah yang berfungsi diseminasi dan komunikasi pengetahuan yang dikembangkan oleh para peneliti pusat studi kepada pengguna (masyarakat) belum dilakukan secara optimal. Diseminasi publikasi hasil penelitian yang kedudukan sangat penting belum digunakan sebagai alat mengukur (indikator) untuk mengetahui kualitas penelitian di pusat studi.

\section{Penutup}

\subsection{Kesimpulan}

Berdasar pada uraian di atas, bahwa manajemen publikasi hasil penelitian yang dilaksanakan oleh pusat studi-pusat studi di Universitas Gadjah Mada belum berstandar baik, melainkan berstandar sedang. Hal ini terjadi penyelenggarakan manajemen publikasi hasil penelitian pada pusat studi sekedar berjalan, tetapi belum dilaksanakan secara optimal.

\subsection{Saran}

Penelitian ini masih perlu dilanjutkan dengan sebuah penelitian yang mampu mengungkap faktorfaktor yang menjadi kendala dan faktor-faktor pendukung dengan penggalian data mendalam, atau sebuah penelitian yang mengungkap tingkat pemanfaatan mahasiswa dalam kebutuhan referensi penelitian tesis untuk mahasiswa $\mathrm{S} 2$ atau penelitian disertasi untuk mahasiswa S3 sehingga dapat diukur tingkat kontribusinya dalam mendukung misi universitas. Bagi universitas. Hasil penelitian tesis ini diharapkan dapat dijadikan bahan masukan dalam menyusun program-program ke depan berkaitan dengan pengembangan publikasi hasil penelitian yang dilakukan oleh semua unit yang ada di UGM, baik itu fakultas maupun pusat studi. Tidak dipungkiri lagi bahwa penetapan program-program yang baik tidak selalu harus datang dari konsepkonsep teoritis yang sangat masih abstrak, tetapi hasil penelitian ini akan nampak lebih terlihat sebagai masukkan dalam penetapan program universitas khususnya bidang publikasi hasil penelitian.

\section{DAFTAR PUSTAKA}

Peraturan Rektor nomor: 346/P/SK/HT/2008 Tentang Kinerja Riset Universitas Gadjah Mada, 27 Juli 2008

Laporan Tahunan 2006 Universitas Gadjah Mada, Gama Press, Yogyakarta,

Universitas Gadjah Mada. 2004. Hasil Penelitian Berpotensi, Lembaga Penelitian Universitas Gadjah Mada, Yogyakarta 2004

Lembaga Penelitian Universitas Brawijaya, Penjaminan Mutu Publikasi, Malang, 2008, bab II hal. 1-2 Lembaga Ilmu Pengetahuan Indonesia, Penjaminan Mutu Publikasi, LIPI, Jakarta, 2008, hal. 1

Abdullah, Amin, 2007, Dasar-Dasar IImu Perpustakaan dan Informasi, Fakultas ADAB, UIN, Yogyakarta.

Abrar, Ana Nadhya, 2004, Rektor-Rektor Universitas Gadjah Mada: Biografi Pendidikan, Gadjah Mada University Press, Yogyakarta

Handoko, T. Hani, 2003, "Manajemen", BPFE Fakultas Ekonomi UGM, Yogyakarta.

Jalaluddin Rakhmat, 2007, "Metode Penelitian Komunikasi", PT Remaja Rosdakarya,Bandung Kadir, Abdul, 2003, Pengenalan Sistem Informasi, Andi Ofset, Yogyakarta

Kadir, Abdul, 2003, Pengenalan Teknologi Informasi, Andi Ofset, Yogyakarta

Ladjamudin, Al-Bahra, 2005, Analisis dan Desain Sistem Informasi, Graha Ilmu, Yogyakarta,

Muhammad Idrus, 2007, "Metode Penelitian IlmuIlmu Sosial" UII Press, Yogyakarta

Muninjaya, 2003, Langkah-langkah Penyusunan Proposal dan Publikasi Ilmiah, EGC Jakarta 
Ngurah Putra, I Gusti, 1999, Manajemen Hubungan Masyarakat, Andi Ofset, Yogyakarta.

Prawirosentono, Suyadi, 2007, Manajemen Operasi: Analisis dan Studi Kasus, Penerbit Bumi Aksara, Jakarta

Rachmat Kriyantono, 2007, "Teknik Praktis Riset Komunikasi", Kencana Prenda Media Group, Jakarta Robandi, Iman, 2008, Becoming the Winner: Riset Menulis Ilmiah, Publikasi Ilmiah, dan Presentasi, Jakarta, Rozaq, Abdul, 2003, Strategi Pengembangan Kinerja Penelitian di Era Otonomi Perguruan Tinggi, LPPM UGM, Yogyakarta

Tjiptono, Fandy, 1996, "Manajemen Jasa", Andi Ofset, Yogyakarta

Wiranto, FA, 2008, Perpustakaan dalam Dinamika Pendidikan dan Kemasyarakatan, UNIKA Soegija Pranata, Semarang 